\title{
The chemical composition of silages produced in a Mediterranean climate
}

\author{
C.J.C. Muller ${ }^{\#}$, J.A. Botha, A.M. Engelbrecht and E.D. D'Hangest D'Yvoy \\ Chief Directorate: Agriculture, Private Bag X1, Elsenburg, 7607 \\ \#Email: carelm@wcape.agric.za
}

\section{Introduction}

Feed cost is a major cost item in all dairying systems. The feed costs of dairies in the Swartland region of the Western Cape varies from 70 to $80 \%$ of total costs (Van der Spuy, 1998). This area has a Mediterranean climate and winter-growing crops such as oats, barley, wheat and lupins are cultivated for feed production. The amount and quality of concentrates fed to dairy cows depends on the type of roughage that is available (Stewart et al., 1995). The concentrate portion of the total diet for dairy cows is a major cost factor as roughages produced in this area generally contain low crude protein (CP) levels while cows are of high genetic potential requiring higher concentrate levels than are available under pasture based systems. To formulate total mixed rations (TMR) and concentrate mixtures, dairy farmers and their advisors should know the chemical composition of roughages normally produced in this area. South African literature in this field is relatively scarce. Van der Merwe \& Smith (1991) and Dugmore (1995) only provide information on the chemical composition of oats, lupin and oats/lupin silages. To obtain more information in this regard a study was conducted by the Silage Interest Group of the Dairy Liaison Committee of the Western Cape Department of Agriculture to determine the chemical composition of silages normally produced in this area. The effect of wilting of green material before ensiling in big bales on the chemical composition of silages was also determined.

\section{Material and Methods}

About 120 samples of seven silage crops were collected during 1996 on five farms in the PiketbergEendekuil area of the Swartland. Samples were randomly collected from silage crops made in big bales, sealed in plastic bags and kept in cooler bags until arrival at Elsenburg where samples were kept in a freezer to be analyzed for chemical composition. After defrosting, samples were dried over three days at $55^{\circ} \mathrm{C}$. Dried material of all samples was milled and subjected to laboratory analysis for CP content according to the method of the AOAC (1984). The in vitro organic matter digestibility (IVOMD) was determined according to the method of Engels \& Van der Merwe (1967). The methods of Van Soest (1983) and Van Soest \& Wine (1967) were used to determine the acid detergent fiber (ADF) and neutral detergent fiber (NDF) contents, respectively. The pH of silages was determined after defrosting. Samples from all farms within a silage crop were pooled and the mean and standard deviation of each component calculated. The effect of the quality of silages on the cost of TMR's was determined by least cost ration formulation.

\section{Results and Discussion}

Comparing the chemical analysis of silages with feeding tables generally in use by advisors and farmers is complicated because of different sampling techniques, laboratory analysis methods, cultivar and environmental differences. Mean values for some of the feed components of silages were lower than available tabled values (Table 1). This is probably an indication of macro and micro environmental differences between silages produced in different parts of South Africa. Generally soil types in the Swartland area are of medium to poor quality requiring liberal amounts of fertilizers. Wilting of material before ensiling had little effect on the chemical composition of silages. Only ADF and NDF contents were reduced $(\mathrm{P}<0.05)$ by wilting in some crops such as triticale, sweet lupins and oats/barley, wheat and oats/vetch mixtures. The chemical analysis for all components of oat silage obtained from three farms differed $(\mathrm{P}<0.01)$ showing the effect of growth stage at ensiling. The $\mathrm{CP}$ content varied from 6.0 to $10.0 \%$ (on DM basis) while ADF and NDF levels were lower (35.8 vs 39.8\% and 53.4 vs $64.6 \%$ on DM basis) for oat silage made at the pipe to early dough stages. Because of the large variation between samples, it is clear that a single analysis would not be sufficient to determine the quality of a specific feedstuff. Poor sampling techniques could also effect the chemical composition of feeds. The calculated cost of TMR based on the highest and lowest values of feed components of roughages differed, with higher TMR costs when lowest values were used. TMR costs differed between R30 and R80/ton for barley-wheat and oat based diets. When using 
Short paper and poster abstracts: $38^{\text {th }}$ Congress of the South African Society of Animal Science

sweet lupin as a roughage source, TMR cost was the lowest, indicating the advantage of a roughage with a high CP-content.

Table 1 The chemical analysis (values on DM basis) of silages produced in the Eendekuil-Piketberg area of the Western Cape (s.d: standard deviation)

\begin{tabular}{|c|c|c|c|c|c|c|c|}
\hline \multirow{2}{*}{ Parameters } & \multirow{2}{*}{ Oats } & \multirow{2}{*}{ Triticale } & \multirow{2}{*}{ Sweet lupin } & \multirow{2}{*}{$\begin{array}{l}\text { Barley } \\
\text { wheat }\end{array}$} & \multirow{2}{*}{$\begin{array}{c}\text { Mixtures } \\
\text { Oats/ Triticale }\end{array}$} & \multirow[b]{2}{*}{$\begin{array}{l}\text { Oats/ barley } \\
\text { wheat }\end{array}$} & \multirow[b]{2}{*}{ Oats/Vetch } \\
\hline & & & & & & & \\
\hline Number of samples & 34 & 19 & 12 & 9 & 12 & 25 & 12 \\
\hline $\mathrm{pH}$ & 4.06 & 3.99 & 3.98 & 4.03 & 4.17 & 3.98 & 3.85 \\
\hline \multicolumn{8}{|l|}{$\mathrm{CP}(\%):$} \\
\hline Mean (sd) & $7.6(1.8)$ & $9.5(0.9)$ & $13.5(1.7)$ & $9.3(0.05)$ & $8.6(1.0)$ & $9.2(1.5)$ & $12.1(0.6)$ \\
\hline Range & $4.7-11.3$ & $8.1-11.6$ & $11.6-16.3$ & $8.4-9.9$ & $8.4-9.7$ & $5.7-13.4$ & $11.3-13.3$ \\
\hline \multicolumn{8}{|l|}{$\operatorname{ADF}(\%):$} \\
\hline Mean (sd) & $38.1(4.8)$ & $38.8(2.1)$ & $46.3(3.3)$ & $40.2(1.5)$ & $37.9(2.4)$ & $40.0(2.4)$ & $37.7(2.4)$ \\
\hline Range & $30.8-45.7$ & $35.3-43.7$ & $39.3-51.1$ & $37.9-42.5$ & $34.5-42.7$ & $34.9-44.2$ & $35.0-43.4$ \\
\hline \multicolumn{8}{|l|}{$\operatorname{NDF}(\%):$} \\
\hline Mean (sd) & $59.7(5.3)$ & $60.4(2.3)$ & $56.4(2.8)$ & $63.6(1.7)$ & $61.8(2.2)$ & $62.3(2.4)$ & $52.8(1.7)$ \\
\hline Range & $50.0-69.2$ & $56.6-63.8$ & $51.8-62.2$ & $61.4-67.5$ & $58.1-66.4$ & $58.0-66.9$ & $50.9-55.7$ \\
\hline \multicolumn{8}{|l|}{ TDN (\%): } \\
\hline Mean (sd) & $69.1(4.6)$ & $62.6(4.9)$ & $62.7(3.4)$ & $61.7(2.1)$ & $66.3(1.2)$ & $63.1(4.2)$ & $69.6(0.9)$ \\
\hline Range & $58.5-75.7$ & $54.9-71.3$ & $55.3-67.5$ & $58.8-66.2$ & $64.6-68.4$ & $56.1-70.2$ & $68.2-72.1$ \\
\hline \multicolumn{8}{|l|}{$\mathrm{Ca}(\%):$} \\
\hline Mean (sd) & $0.18(0.04)$ & $0.19(0.04)$ & $0.68(0.07)$ & $0.23(0.02)$ & $0.31(0.02)$ & $0.24(0.06)$ & $0.49(0.11)$ \\
\hline Range & $0.16-0.18$ & $0.14-0.28$ & $0.57-0.80$ & $0.18-0.26$ & $0.28-0.34$ & $0.18-0.38$ & $0.36-0.77$ \\
\hline \multicolumn{8}{|l|}{$\mathrm{P}(\%):$} \\
\hline Mean (sd) & $0.19(0.02)$ & $0.25(0.04)$ & $0.29(0.03)$ & $0.20(0.03)$ & $0.23(0.01)$ & $0.20(0.03)$ & $0.21(0.02)$ \\
\hline Range & $0.18-0.20$ & $0.17-0.32$ & $0.25-0.35$ & $0.17-0.24$ & $0.20-0.25$ & $0.16-0.30$ & $0.18-0.23$ \\
\hline
\end{tabular}

\section{Conclusions}

The CP content of oat silage varied to a great extent between farms indicating the effect of different soil types, fertilizer application rates and growth stage at harvesting. Although the coefficients of variance for most silages and feed components were not large, attention should be given to the range in values obtained from the chemical analysis. This indicates a need to have feeds regularly analyzed. Roughages with higher CP-levels resulted in the lowest TMR cost.

\section{References}

AOAC, 1984. Association of Official Analytical Chemists. Washington USA.

Dugmore, T.J., 1995. Dairying in Kwazulu-Natal. Pietermaritzburg.

Engels, E.A.N. \& Van der Merwe, F.J., 1967. S. Afr. J. Agric. Res. 10, 983.

Stewart, P.G. et al., 1995. Dairying in Kwazulu-Natal. Pietermaritzburg

Van der Merwe, F.J. \& Smith, W.A., 1991. Dierevoeding. Cape Town.

Van der Spuy, A.L., 1998. Department of Agriculture, Elsenburg.

Van Soest, P.J., 1983. J. Assoc. Off. Anal. Chem. 46: 82.

Van Soest, P.J. \& Wine, R.H., 1967. J. Assoc. Off. Anal. Chem. 50: 50. 